\title{
Revealing How Coca Cola Successfully Broke into Indonesia Market with a Coke
}

\author{
Donny Susilo \\ Asia University \\ No. 500, Liufeng Road, Wufeng District, Taichung City, Taiwan 41354 \\ Donnysusilo777@gmail.com \\ Web of Science Researcher ID: AAW-4485-2020
}

\begin{abstract}
Indonesia has been attractive investment destination to many multinational companies since a long time ago, due to its big population, plenty natural resources and cheap labors, including to Coca Cola. This study aims to analyze international market entry and business strategy of Coca Cola when entering Indonesia market. Moreover, this study also aims to identify internal and external factor that affects Coca Cola business in Indonesia by SWOT analysis, resulting in growth strategy recommendation. The result reveals out that Coca Cola came to Indonesia by foreign direct investment at first time, but then decided to expand their distribution all over Indonesia. Therefore, they opened an opportunity for franchise. By keeping their secret formula, they can provide differentiation that makes them remains competitive. The strategy adopted by Coca Cola Amatil Indonesia to conquer Indonesia market is transnational strategy, which has characteristics of high in local responsiveness and also high in global integration. Meanwhile, the SWOT analysis suggests that Coca Cola should put priority on market penetration first instead of market development for the time being. Company should focus on sales and distribution in specific market first then explore more market for their product. There are still many possible markets to exploit in Indonesia as well as abroad.
\end{abstract}

Keywords: international business, transnational strategy, new market entry, multinational company

JEL Classification: F23, M16

\section{INTRODUCTION}

International investment cannot be ignored since it is a strategic movement to gain more foreign exchange that will positively contribute to economic growth in a country. Indonesia is a big emerging market and therefore it always become point of attractions for many foreign investors to come and take advantage of its rapid industrial development. Supported by pro-investment policies from Indonesian governments, many multinational enterprises successful step their foot in Indonesia, one of them that is now listed in Fortune 500 is Coca Cola. What brings Coca Cola to be one of the most successful multinational company in Asia is their differentiation strategy, they have unique product with secret formula to be produced at low cost. Today, Coca Cola has 20 soda brands, offering market many options from healthy non calories soda and others, the large portfolio increases its brand reputation that has been previously been famous as a giant global brand (Jones \& Comfort, 2018).

In spite of high potential market that Indonesia has, many multinational companies were still failed to enter and survive in Indonesia market, thus it becomes interesting research gap to observe further for example Walmart and 7-11. This study aims to analyze international market entry strategy choice of Coca Cola when entering Indonesia market by adopting international business strategy theory from Bartlett and Ghoshal. Moreover, this study also aims to identify internal and external factor that affects Coca Cola business in Indonesia by SWOT analysis. Growth strategy will then be recommended by using its internal strength and opportunity to deal with its internal weakness and threat.

\section{LITERATURE REVIEW \\ Coca Cola Amatil Indonesia}

The Coca-Cola soft drink was founded by Dr. John S. Pemberton, a pharmacist and beverage expert from Atlanta, Georgia, United States in May 1889. Then seeing that the product was promising, it was massively produced by Asa G. Handler in Atlanta 1892, who also patented the Coca-Cola trademark. This company is the parent of all bottling companies that have the Coca-Cola trademark in all countries around the world by providing its consecrate raw materials. Starting in 1893, The Coca-Cola Company built its factory outside of Atlanta. President of The Coca-Cola Company, Robert W. Wouldruff, was the first person to come up with the idea that Coca-Cola drink could be enjoyed not only by Americans, but also for consumption by all nations in the world. To realize this idea, in 1929 the Coca-Cola Cooperation was established, a company that handles the process of selling drinks throughout the country in the world with the same characteristics, quality, taste and freshness.

In history, the sales of Coca-Cola in America was successful, thus they began to internationalize since 1920 . The bottling company partner business of 
The Coca-Cola Company which circulates around the world is an independent business. These companies use flavors and preservatives, which are basic beverage ingredients, produced by The Coca-Cola Company to dissolve it in syrup, then carbonate it and then package it in bottles to be marketed in their respective operational areas. This bottling system is a unique trade start in the history of franchise trading (Franchise System), which is a mutually beneficial collaboration between two companies, namely The Coca-Cola Company and a company, in this case The Coca-Cola Company with a beverage bottling company. These two companies have completely separate management and capital ownership systems

PT. Coca-Cola entered Indonesia market in 1927, when De Nederland Indische Mineral Water Fabriecj (Dutch Indies Mineral Water Factory) bottled it for the first time in Batavia (Jakarta). In 1971 the first modern bottling plant in Indonesia was established under the new name PT. Jaya Beverages Bottling Company. In Indonesia, The Coca-Cola Company through PT. Coca-Cola Indonesia partners with CocaCola Amatil (CCA), a network of bottling factories that has licenses from the largest The Coca-Cola Company trademarks. Until now, CCA is supported by 11 bottling factories and around 9,000 employees serving more than 400,000 customers throughout the archipelago. Coca-Cola Amatil Indonesia (CCAI) provides all variants of the company's products, including bottled drinking water in all parts of the country, except North Sulawesi. CCAI owns and operates 8 bottling factories located in Cibitung, Cikedokan, Bandung, Semarang, Surabaya, Bali, Medan and Lampung. In our system there is also Commercial Product Supply Indonesia (CPS), which focuses on the production of basic beverage ingredients for bottling plants. Apart from Indonesia, CPS also exports its products to neighboring countries such as Singapore, Australia, New Zealand, Cambodia, Vietnam and Thailand. In addition, there is also The Coca-Cola Company, the trademark owner and concentrate provider of Coca-Cola products for local bottling partners. Meanwhile, the local service office, Coca-Cola Indonesia (CCI), focuses on marketing corporate brands in Indonesia.

\section{Global Business Strategy}

There are many ways a company can enter foreign market. According to Bartlett and Ghoshal (2002), there are four ways multinational company can enter a foreign market, which are standardization, export, transnational and multidomestic strategy.
Picture 1. International Business Strategies

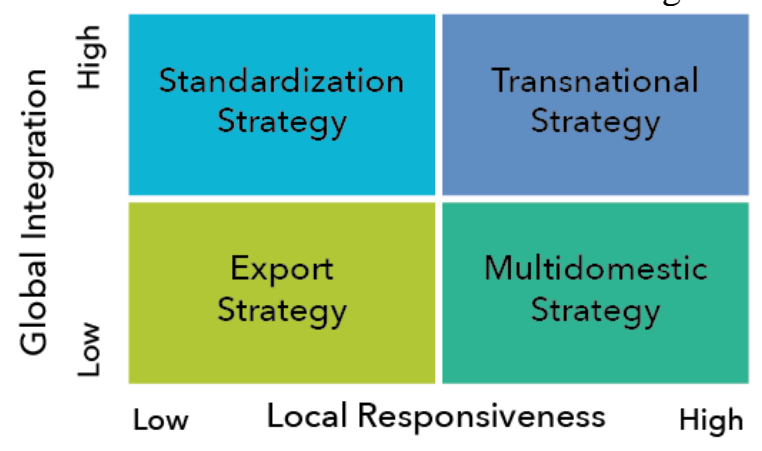

\section{Export Strategy}

Source: Bartlett and Ghoshal (1989)

According to the picture above, the export strategy has a low local response rate because we are exporting or working on a license, the advantage of cost efficiency is little because it uses a production process that is not close to its new market. However, this strategy is the easiest compared to the others because exports only need a few changes while the license only poses a small risk to the holder.

\section{Multidomestic Strategy}

This strategy is a decision spread across each country to increase local responsiveness by dividing authority or decentralization which means giving significant autonomy. This is done by establishing branch companies, providing independent franchises or joint ventures.

\section{Standardization strategy}

The Global Strategy is a decentralized decision whereby the head office coordinates standardization and learning among facilities. This strategy is appropriate to apply when companies focus on cost efficiency but local response is low.

\section{Transnational Strategy}

This strategy combines the benefits and efficiency of a global scale with a local response. This strategy describes a condition where all inputs, whether material, labor or thought, go outside the national boundaries. For companies that use this strategy, the main activities are not centralized in the parent company but each branch carries out its own duties. However, even though it is spread out, it is focused so that it is efficient and flexible in an interconnected network.

\section{SWOT Analysis}

SWOT analysis is the systematic identification of various factors to formulate a company strategy, this analysis is based on logic that maximizes strengths and opportunities, but simultaneously minimizes 
weaknesses and threats. This analysis is based on the assumption that an effective strategy will maximize existing strengths and opportunities and minimize weaknesses and threats. When applied accurately, these simple assumptions have a profound impact on the design of a successful strategy and a business environment analysis that provides the information needed to identify opportunities and threats within the company (Gürel \& Tat, 2017).

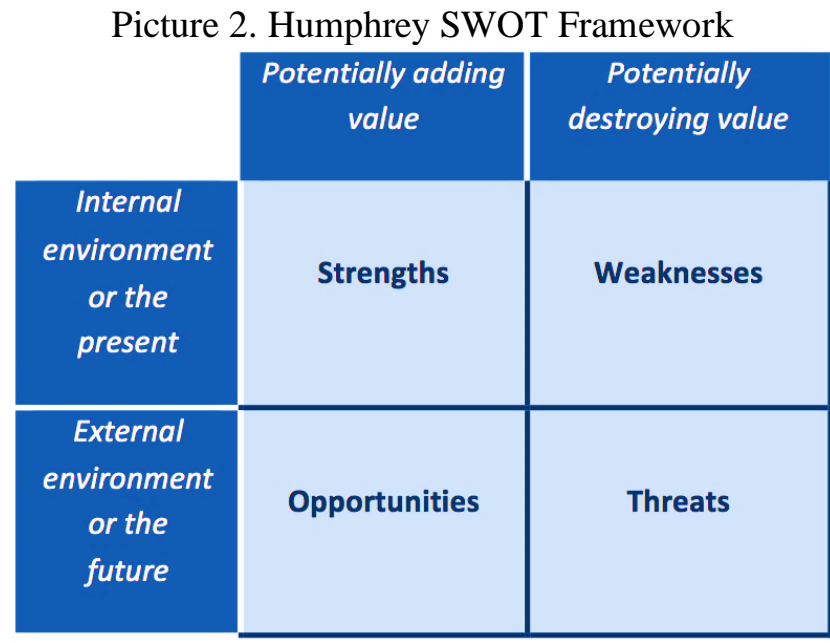

Source: Gürel and Tat (2017)

\section{METHOD}

This study is qualitative descriptive research because it involves non-numerical data and presents the result in description style. The qualitative data in this study were collected from interview, secondary data and official documents. After that the data was collected, it was then processed and explained accordingly to test hypotheses or answer questions about the current status of research subjects.

The data was taken from two sources, namely secondary data and primary data. Primary data is data that a person collects directly from the object under study and for the purposes of the study concerned, which was in the form of interviews and observations. Primary data is the result of interview and observation at the PT Coca Cola Amatil Indonesia Office. Then secondary data was data obtained and collected from previous research published by various other trustworthy agencies. Secondary data in this study are in the form of documents and study literature.

SWOT framework was used to analyze the company's internal (strengths and weaknesses) and external (opportunities and threats) environment which is the basis for conducting a SWOT analysis. SWOT analysis is carried out through the IFE (Internal Factor
Evaluation) matrix which will describe the biggest strengths and weaknesses of the company and the EFE (External Factor Evaluation) matrix which will describe the opportunity and threat factors that the company has and the IE (Internal External) matrix which shows where the company's current position. Moreover, global business strategy diagram by Bartlett, C.A. \& Ghoshal was also utilized to explain the strategy of Coca Cola in Indonesia market.

\section{DISCUSSION}

\section{Analysis of Indonesia Market}

Indonesia is a big market with about 250 million population, make it as the biggest market in South East Asia. Indonesia large population enables the company to produce massively at lower cost because of lower labor cost. On recently, Indonesia government has approved omnibus bills on job creation and taxation, giving Coca Cola many opportunities as the bill will simplify licensing procedure, labor and land procurement for new factory (Kim, 2021). It will also decrease corporate tax from $25 \%$ to $20 \%$ by 2023 and simplify the process of inviting expatriate to come and work in Indonesia (Gorbiano, 2019). On the other side, the new bills will stimulate other multinational enterprises (MNEs) to enter Indonesia market and make the competition tighter for Coca Cola. The bills will allow Coca Cola to invite qualified expatriates to strengthen research and development for their product to match the taste of Indonesia people (Anggraeni \& Rachman, 2020). Indonesia government is also moving forward to welcome industry 4.0 and therefore the government has urgently pushed all manufactures to adopt it. The digitalization in manufacturing process will give opportunity for Coca Cola to increase their profitability and cost efficiency, although it usually needs a large initial investment in the beginning. Coca Cola Amatil Indonesia has recently been awarded INDI 4.0 by Indonesia government for its readiness for industry 4.0, the assessment was based on 5 aspects, respectively management and organization, human capital management, culture, product and service, technology and manufacturing (Maskur, 2019).

In addition, Indonesian government also focuses on infrastructure development, governments are aggressively investing in inland and sea tolls construction, the concept will bring benefit to manufacturing company like Coca Cola in the aspect of distribution cost, the company can distribute their product faster and cheaper than before to all over Indonesia regions, reaching up to areas that have not 
been reached before, it can simplify distribution process that can lead to cheaper price for the end users (Saputra et al, 2018). The heating trade war between The U.S and China may also indirectly affect American MNEs in Indonesia, there are many American companies suffer from the trade war and it increases their willingness to move out from China and set up their company in Indonesia and other South East Countries that has almost similar characteristics with China in term of labor cost. Even if Coca Cola Amatil Indonesia was not heavily impacted by the tariff war because the factory is in Indonesia but in the future, there may be more MNEs coming to Indonesia market and make market more competitive because Indonesia consumers will be subject to many more innovative products (Jones \& Comfort, 2018).

\section{Coca Cola's Strategy in Indonesia}

Coca Cola has a very long history in entering Indonesia market. Back in 1990s, Coca Cola headquarter in Atlanta, USA made foreign direct investment to many countries all over the world including Indonesia. From time to time, the product became more famous and demanded by local market in Indonesia, thus company planned to sell it in bottle and make it available all over retail stores therefore they expanded their business by cooperating with existing companies in Indonesia, giving them license to produce according the secret formula and the cooperation was well-known as franchise. The story of Coca Cola founder, John S Pemberton who followed Isaac Singer, as founder of franchise system has been known worldwide. At first time, they enjoyed a lot of advantage from foreign direct investment, especially in term of formula security because they came up a unique innovation, therefore coming in by foreign direct investment will secure the secret formula from other shareholders, however this method is effective when multinational companies have a lot of financial resource and dare to take a risk of entering a new foreign market (Haudi \& Cahyono, 2020). At that time, Coca Cola was already successful in western countries, therefore giving company a lot of financial resource. Supported by its country image and market research (Mikler \& Ronit 2020), finally the product was accepted by Indonesian people. Foreign direct investment also allows company to operate under one command, effective to avoid conflict because they have no new partner in the host country, they can make decision faster by putting priority to their original vision and mission.

Nevertheless, after sometimes finally company opened collaboration opportunity with local companies instead of build up or purchase new factory when they had to expand their business and produce bottling in more areas. The local companies were permission to produce with Coca Cola brand and trademark. Coca Cola helped with the management system and gained a profit sharing from each local company that has specific area to distribute the product. This strategy is beneficial for Coca Cola Company in term of efficiency, because they do not have to spend a lot of start-up cost, the factory is already available and therefore they can operate faster under the franchise system (Rosado-Serrano, 2017). Coca Cola brand has been famous and thus considered as win-win solution by local companies that are usually called as franchisees. Each franchisee's performance will be evaluated periodically and mentored when facing problem by the franchisor. However this strategy also has disadvantage because Coca Cola can only take some profit sharing from the income and usually lower than joint venture considering that the franchisee is the one that works hard. When franchisee does a mistake that creates a public relation nightmare, the franchisor's brand will be damaged therefore Coca Cola headquarter must work hard to supervise all of their franchisees all the time. There is also a high risk that their secret formula is stolen by other competitors when they are betrayed by their own franchisees.

The strategy adopted by Coca Cola Amatil Indonesia to conquer Indonesia market is transnational strategy. The main characteristics of this strategy are high local responsiveness and high in global integration. This is quite hard to do but big companies such as Coca Cola and Unilever already perform this well. Coca Cola has standardized product which basically is their secret formula that they sell all over the world, they do not change the formula without permission from headquarter because it is core value of their product and it is their innovation that differentiate them from competitors by far. The same thing also happens to their bottle packaging. However, in downstream activities such as marketing and sales, the company is more adaptive the local people and tend to use local actress as the brand ambassador. Coca Cola Amatil Indonesia today uses tagline "Rasakan Momennya", which is in translation "Feel the moment" for their Indonesia marketing campaign and chose Tatjana Saphira, Eva Celia Latjuba, and Arifin Putra, famous young Indonesia actress as their brand ambassadors because they believe it is suitable with their primary target market, young people. Coca Cola Amatil Indonesia is also aware that Indonesia is a tropical country, it makes the weather is hot and 
therefore most of their product are sold as cold drink in display cooler, even in both traditional and modern stores people most often find Coca Cola in display cooler.

Their marketing strategy is also adjusted to host country and they actively initiate corporate social responsibility program that focuses on sustainability issue, they have large distribution network and supply that can reach every region to optimize their profit and take advantage from market penetration. Their marketing is focused on young people even if sometimes older people are targeted as well. The niche strategy is efficient and effective to strengthen their brand awareness. The strategy is fit because each market has its own characteristic and Coca Cola has realized that consumers in Indonesia are different from consumers in the U.S, therefore it is important to be adaptive. This is because the culture in two countries is different and culture evolves from time to time (Susilo, 2018). The strategy is good because it allows company to conquer different consumers in different market but still keep their original innovation as the most competitive value against their competitors.

However this strategy is rather costly because they have to make research and different promotion material in each country. The inflexibility in its product customization is also a weakness because it does not allow them to adapt to other market segment and push consumers to like their product instead of listening to their want and need. When the product is new, they must also spend a lot of budget to educate consumers in the host country about their product, people in new market may be afraid of health issue when they hear about Coca Cola at very first time because it can be used to clean up our toilet. In term of $R \& D$, even if Coca Cola has set up research center in other country such as Belgium and India, but it does not still have one in Indonesia market. The centralized R\&D activity is because they want to keep their secret formula and they still believe that Indonesian people love their secret formula.

\section{SWOT Analysis for Coca Cola Amatil Indonesia}

Table 1. Opportunities for Coca Cola in Indonesia

\begin{tabular}{|c|c|c|c|c|}
\hline & \multicolumn{4}{|c|}{$\begin{array}{l}\text { External Factor Evaluation Matrix } \\
\text { (EFE) }\end{array}$} \\
\hline & Opportunities & Weight & $\underline{\text { Rating }}$ & $\frac{\text { Weighted }}{\text { Score }}$ \\
\hline 1. & $\begin{array}{l}\text { The election season will } \\
\text { increase demand for } \\
\text { soft drinks such as coca } \\
\text { cola as there will be }\end{array}$ & 0.70 & 1 & 0.70 \\
\hline
\end{tabular}

\begin{tabular}{|lll|}
\hline & $\begin{array}{l}\text { many meetings and } \\
\text { events }\end{array}$ \\
\hline 2. & $\begin{array}{l}\text { Government visa-free } \\
\text { policies increases the } \\
\text { sale of food and } \\
\text { beverages at tourist } 0.70\end{array}$ \\
attractions and result in \\
increasing demand for \\
soft drinks
\end{tabular}

Table 2. Threats for Coca Cola in Indonesia

\begin{tabular}{|c|c|c|c|c|}
\hline & Threats & Weight & Rating & $\frac{\text { Weighted }}{\text { Score }}$ \\
\hline & $\begin{array}{l}\text { The paid plastic bag } \\
\text { policy for minimarkets } \\
\text { and supermarkets is to } \\
\text { reduce non- } \\
\text { environmentally } \\
\text { friendly plastic waste } \\
\text { and stimulate plastic } \\
\text { producers to do green } \\
\text { innovation }\end{array}$ & 0.70 & 2 & 1.40 \\
\hline 2. & $\begin{array}{l}\text { Minimum wage for } \\
\text { labour who works in } \\
\text { Indonesia has been } \\
\text { adjusted by government } \\
\text { to increase }\end{array}$ & 0.70 & 3 & 2.10 \\
\hline & $\begin{array}{l}\text { Imports of plastic } \\
\text { material are assumed to } \\
\text { be lacking therefore the }\end{array}$ & 0.70 & 3 & 2.10 \\
\hline
\end{tabular}


price of supply may

increase due to scarcity

4. The price of imported plastic raw materials is still very much affected by fluctuations in the rupiah exchange rate which tend to weaken lately

5. There is growing awareness of the Indonesian people to reduce drinking soft

$\begin{array}{lll}0.70 & 2 & 1.40\end{array}$

drink because it is claimed unhealthy

6. Society trend is shifting from the use of conventional plastic to eco-friendly plastics or recyclable bio plastics affect food and $\begin{array}{lll}0.70 & 2 & 1.40\end{array}$ beverage producers such Coca Cola to issue eco-friendly packaging

7. Covid-19 crisis has impacted economy as whole and decrease demand for soft drinks because less people go out and meet with each other

\section{TOTAL} 4 3.20

The total score for EFE matrix 28.10 is above the average of 2.5 which indicates that company's strategies are well designed to meet the opportunities and defend against threats.

Table 3. Strengths for Coca Cola in Indonesia

Internal Factor Evaluation

Matrix (IFE)

\begin{tabular}{|c|c|c|c|c|}
\hline \multicolumn{2}{|c|}{ Strengths } & Weight & \multirow{2}{*}{$\frac{\underline{\text { Rati }}}{\underline{\text { ng }}}$} & \multirow{2}{*}{$\frac{\frac{\text { Weight }}{\text { ed }}}{\text { Score }}$} \\
\hline 1. & $\begin{array}{l}\text { Good organizational } \\
\text { structure and experience } \\
\text { in global business }\end{array}$ & 0.10 & & \\
\hline 2. & $\begin{array}{l}\text { A strong brand equity of Coca } \\
\text { Cola because it has been } \\
\text { worldwide }\end{array}$ & $\begin{array}{c}0.1 \\
0\end{array}$ & 4 & 0.40 \\
\hline 3. & $\begin{array}{l}\text { Coca Cola actively implement } \\
\text { sustainability based corporate } \\
\text { social responsibility program } \\
\text { and build good relationship } \\
\text { with stakeholders }\end{array}$ & $\begin{array}{c}0.1 \\
0\end{array}$ & 3 & 0.30 \\
\hline 4. & $\begin{array}{l}\text { The product is innovative and } \\
\text { the secret formula is their great } \\
\text { asset }\end{array}$ & $\begin{array}{c}0.1 \\
0\end{array}$ & 4 & 0.40 \\
\hline 5. & $\begin{array}{l}\text { A lot of distribution channels in } \\
\text { Indonesia, mini markets have } \\
\text { cold storage }\end{array}$ & $\begin{array}{c}0.1 \\
0\end{array}$ & 4 & 0.40 \\
\hline
\end{tabular}

Table 4. Weaknesses for Coca Cola in Indonesia

\begin{tabular}{|c|c|c|c|c|}
\hline & Weaknesses & Weight & Rating & $\frac{\text { Weighted }}{\text { Score }}$ \\
\hline 1. & $\begin{array}{l}\text { Coca Cola has to adjust } \\
\text { with local culture } \\
\text { because it comes from } \\
\text { the west and there are } \\
\text { some significant } \\
\text { cultural differences } \\
\text { between western } \\
\text { countries and eastern } \\
\text { countries }\end{array}$ & 0.10 & 2 & 0.20 \\
\hline 2. & $\begin{array}{l}\text { There are some claims } \\
\text { and studies that Coca } \\
\text { Cola is unhealthy drink }\end{array}$ & 0.10 & 1 & 0.10 \\
\hline 3. & $\begin{array}{l}\text { There are some negative } \\
\text { publications about Coca } \\
\text { Cola factory waste that } \\
\text { becomes problem in } \\
\text { some countries, for } \\
\text { example India }\end{array}$ & 0.10 & 2 & 0.20 \\
\hline 4. & $\begin{array}{l}\text { Limited range of } \\
\text { product that only cover } \\
\text { drink }\end{array}$ & 0.10 & 2 & 0.20 \\
\hline 5. & $\begin{array}{l}\text { The competition is } \\
\text { getting harder in } \\
\text { Indonesia especially } \\
\text { with Fanta, Sprite, Big } \\
\text { and J\&W }\end{array}$ & 0.10 & 2 & 0.20 \\
\hline & TOTAL & 1.00 & & 2.70 \\
\hline
\end{tabular}

The total score for IFE matrix 2.7 is above the average of 2.5 which indicates that company's internal situation is a bit strong against its competitor however it is slightly above the average therefore a lot of improvement is required to increase company's competitiveness in the market

\section{Quantitative Strategic Planning Matrix}

Table 5. Quantitative Strategic Planning Matrix of Coca Cola in Indonesia

\begin{tabular}{|c|c|c|c|c|c|c|}
\hline & \multirow[b]{2}{*}{ Opportunities } & \multirow[b]{2}{*}{ Weight } & \multicolumn{2}{|c|}{$\begin{array}{c}\text { Market } \\
\text { Development }\end{array}$} & \multicolumn{2}{|c|}{$\begin{array}{c}\text { Market } \\
\text { Penetration }\end{array}$} \\
\hline & & & $\underline{\mathrm{AS}}$ & TAS & AS & TAS \\
\hline 1. & $\begin{array}{l}\text { The election season } \\
\text { will increase demand } \\
\text { for soft drinks such as } \\
\text { coca cola as there will } \\
\text { be many meetings and } \\
\text { events }\end{array}$ & 0.70 & 1 & 0.70 & 2 & 1.40 \\
\hline 2. & $\begin{array}{l}\text { Government visa-free } \\
\text { policies increases the } \\
\text { sale of food and } \\
\text { beverages at tourist } \\
\text { attractions and result } \\
\text { in increasing demand } \\
\text { for soft drinks }\end{array}$ & 0.70 & 1 & 0.70 & 2 & 1.40 \\
\hline 3. & $\begin{array}{l}\text { The government } \\
\text { builds tolls } \\
\text { throughout all of } \\
\text { Indonesia to minimize } \\
\text { cost of distribution }\end{array}$ & 0.70 & 1 & 0.70 & 2 & 1.40 \\
\hline
\end{tabular}




\begin{tabular}{|c|c|c|c|c|c|c|}
\hline & $\begin{array}{l}\text { between factory and } \\
\text { retailer or distributor }\end{array}$ & & & & & \\
\hline 4. & $\begin{array}{l}\text { Currently, } \\
\text { government of } \\
\text { Indonesia gives tax } \\
\text { incentive to industries } \\
\text { that employ a lot of } \\
\text { workers to recover } \\
\text { Indonesia economy } \\
\text { during covid-19 crisis }\end{array}$ & 0.70 & 1 & 0.70 & 2 & 1.40 \\
\hline 5. & $\begin{array}{l}\text { The growth of the } \\
\text { food and beverage } \\
\text { industry which is } \\
\text { predicted to grow to } \\
\text { reach by } 8-9 \% \text { per } \\
\text { year will impact } \\
\text { demand for soft } \\
\text { drinks }\end{array}$ & 0.80 & 1 & 0.80 & 2 & 1.60 \\
\hline 6. & $\begin{array}{l}\text { Indonesia is } \\
\text { populated country } \\
\text { with huge number of } \\
\text { people and the } \\
\text { demand especially } \\
\text { from middle class is } \\
\text { rising }\end{array}$ & 0.70 & 1 & 0.70 & 2 & 1.40 \\
\hline 7. & $\begin{array}{l}\text { There is new more } \\
\text { eco-friendly bio } \\
\text { plastic that can be } \\
\text { used as packaging } \\
\text { material for soft } \\
\text { drinks }\end{array}$ & 0.70 & 1 & 0.70 & 2 & 1.40 \\
\hline & Threats & Weight & $\underline{\mathrm{AS}}$ & $\underline{\text { TAS }}$ & $\underline{\mathrm{AS}}$ & $\underline{\text { TAS }}$ \\
\hline 1. & $\begin{array}{l}\text { The paid plastic bag } \\
\text { policy for } \\
\text { minimarkets and } \\
\text { supermarkets is to } \\
\text { reduce non- } \\
\text { environmentally } \\
\text { friendly plastic waste } \\
\text { and stimulate plastic } \\
\text { producers to do green } \\
\text { innovation }\end{array}$ & 0.70 & 3 & 2.10 & 4 & 2.80 \\
\hline 2. & $\begin{array}{l}\text { Minimum wage for } \\
\text { labour who works in } \\
\text { Indonesia has been } \\
\text { adjusted } \\
\text { government } \\
\text { increase }\end{array}$ & 0.70 & 3 & 2.10 & 4 & 2.80 \\
\hline 3. & $\begin{array}{l}\text { Imports of plastic } \\
\text { material are assumed } \\
\text { to be lacking therefore } \\
\text { the price of supply } \\
\text { may increase due to } \\
\text { scarcity }\end{array}$ & 0.70 & 3 & 2.10 & 4 & 2.80 \\
\hline 4. & $\begin{array}{l}\text { The price of imported } \\
\text { plastic raw materials } \\
\text { is still very much } \\
\text { affected } \\
\text { fluctuations in the } \\
\text { rupiah exchange rate } \\
\text { which tend to weaken } \\
\text { lately }\end{array}$ & 0.70 & 3 & 2.10 & 4 & 2.80 \\
\hline 5. & $\begin{array}{l}\text { There is growing } \\
\text { awareness of the } \\
\text { Indonesian people to } \\
\text { reduce drinking soft } \\
\text { drink because it is } \\
\text { claimed unhealthy }\end{array}$ & 0.70 & 3 & 2.10 & 4 & 2.80 \\
\hline
\end{tabular}

\begin{tabular}{|c|c|c|c|c|c|c|}
\hline 6. & $\begin{array}{l}\text { Society trend is } \\
\text { shifting from the use } \\
\text { of conventional } \\
\text { plastic to eco-friendly } \\
\text { plastics or recyclable } \\
\text { bio plastics affect } \\
\text { food and beverage } \\
\text { producers such Coca } \\
\text { Cola to issue eco- } \\
\text { friendly packaging }\end{array}$ & 0.70 & 3 & 2.10 & 4 & 2.80 \\
\hline \multirow[t]{3}{*}{7.} & $\begin{array}{l}\text { Covid-19 crisis has } \\
\text { impacted economy as } \\
\text { whole and decrease } \\
\text { demand for soft } \\
\text { drinks because less } \\
\text { people go out and } \\
\text { meet with each other }\end{array}$ & 0.80 & 3 & 2.40 & 4 & 3.20 \\
\hline & & & \multicolumn{2}{|c|}{$\begin{array}{c}\text { Market } \\
\text { Development }\end{array}$} & \multicolumn{2}{|c|}{$\begin{array}{c}\text { Market } \\
\text { Penetration }\end{array}$} \\
\hline & Strengths & $\underline{\text { Weight }}$ & $\underline{\mathrm{AS}}$ & $\underline{\text { TAS }}$ & $\underline{\mathrm{AS}}$ & $\underline{\text { TAS }}$ \\
\hline 1. & $\begin{array}{lr}\text { Good organizational } \\
\text { structure } \\
\text { experience in global } \\
\text { business }\end{array}$ & 0.10 & 3 & 0.30 & 2 & 0.20 \\
\hline 2. & $\begin{array}{l}\text { A strong brand equity } \\
\text { of Coca Cola because } \\
\text { it has been worldwide }\end{array}$ & 0.10 & 3 & 0.30 & 2 & 0.20 \\
\hline 3. & $\begin{array}{l}\text { Coca Cola actively } \\
\text { implement } \\
\text { sustainability based } \\
\text { corporate } \\
\text { responsibility } \\
\text { program and build } \\
\text { good relationship } \\
\text { with stakeholders }\end{array}$ & 0.10 & 3 & 0.30 & 2 & 0.20 \\
\hline 4. & $\begin{array}{l}\text { The product is } \\
\text { innovative and the } \\
\text { secret formula is their } \\
\text { great asset }\end{array}$ & 0.10 & 3 & 0.30 & 2 & 0.20 \\
\hline 5. & $\begin{array}{l}\text { A lot of distribution } \\
\text { channels in Indonesia, } \\
\text { mini markets have } \\
\text { cold storage }\end{array}$ & 0.10 & 3 & 0.30 & 2 & 0.20 \\
\hline & Weaknesses & Weight & $\underline{\mathrm{AS}}$ & $\underline{\text { TAS }}$ & $\underline{\mathrm{AS}}$ & $\underline{\mathrm{TAS}}$ \\
\hline 1. & $\begin{array}{l}\text { Coca Cola has to } \\
\text { adjust with local } \\
\text { culture because it } \\
\text { comes from the west } \\
\text { and there are some } \\
\text { significant cultural } \\
\text { differences between } \\
\text { western countries and } \\
\text { eastern countries }\end{array}$ & 0.10 & 0 & 0.00 & 0 & 0.00 \\
\hline 2. & $\begin{array}{l}\text { There are some claims } \\
\text { and studies that Coca } \\
\text { Cola is unhealthy } \\
\text { drink }\end{array}$ & 0.10 & 3 & 0.30 & 0 & 0.00 \\
\hline & $\begin{array}{l}\text { There are some } \\
\text { negative publications } \\
\text { about Coca Cola } \\
\text { factory waste that } \\
\text { becomes problem in } \\
\text { some countries, for } \\
\text { example India }\end{array}$ & 0.10 & 3 & 0.30 & 0 & 0.00 \\
\hline & $\begin{array}{l}\text { Limited range of } \\
\text { product that only } \\
\text { cover drink }\end{array}$ & 0.10 & 0 & 0.00 & 2 & 0.20 \\
\hline
\end{tabular}




\begin{tabular}{lllllll|}
\hline 5. The competition is 0.10 & 0 & 0.00 & 2 & 0.20 \\
getting harder in & & & & & \\
Indonesia especially \\
with Fanta, Sprite, \\
Big and J\&W
\end{tabular}

AS is attractiveness score, usually ranged from 1-4, where:

$1=$ not attractive

$2=$ less attractive

$3=$ quite attractive

$4=$ very attractive

This is level of measurement of how important this factor for our strategy decision making, getting higher the score, getting impactful the factor to our business.

Meanwhile TAS is total of attractiveness score. The QSPM table above states that TAS for market penetration 31.40 is higher than TAS for market development 22.10. This is meaningful conclusion that informs company to put priority on market penetration first instead of market development for the time being. Company should focus on sales and distribution in specific market first then explore more market for their product. There are still many possible markets to exploit in Indonesia as well as abroad.

\section{CONCLUSION AND RECOMMENDATION}

Based in Atlanta, USA, Coca Cola is one of the most successful multinational enterprises in Indonesia, its strategy fits to Indonesia market and its differentiation strategy is the key of competitive advantage that will secure company market in the future. As transnational company that upholds originality and adaptation to the host country, Coca Cola holds a strong position as a promising franchisor, especially because their brand has been known worldwide. They are to focus on local trends and become more aggressive in local sales and marketing in order to grow up their business.

The SWOT analysis resulted in total score for EFE matrix 28.10 is above the average of 2.5 which indicates that company's strategies are well designed to meet the opportunities and defend against threats. Meanwhile, the total score for IFE matrix 2.7 is above the average of 2.5 which indicates that company's internal situation is a bit strong against its competitor however it is slightly above the average therefore a lot of improvement is required to increase company's competitiveness in the market. Coca Cola should put priority on market penetration first instead of market development for the time being. Company should focus on sales and distribution in specific market first then explore more market for their product. There are still many possible markets to exploit in Indonesia as well as abroad.

Indonesia has a lot of potential as emerging economies and the government is friendly to foreign investment, it is both opportunity and threat for Coca Cola Amatil Indonesia, as they can expand and distribute their product more efficiently but also will face tighter competition when new comers show up in the future. It is also important for Coca Cola to set up research center in Indonesia because it allows company to have opportunity if they can find a raw material that can be used for their product formula. Coca Cola is suggested to make more market research, providing digital platform for Indonesian consumers to be more engaged in their product development so that their innovation is not based on their own want, but market want and need (Morgan-Thomas, Dessart \& Veloutsou, 2020). They also need more sponsorship in Indonesian sport or television program to increase their brand awareness and actively give scholarship to show that they care about education in Indonesia. They can also set trend and promote a style of how to enjoy cold Coca Cola drink with fun.

\section{REFERENCES}

[1] Anggraeni, R., \& Rachman, C. I. L. (2020, May). Omnibus Law in Indonesia: Is That the Right Strategy?. In International Conference on Law, Economics and Health (ICLEH 2020) (pp. 180-182). Atlantis Press.

[2] Bartlett, C. A., \& Ghoshal, S. (2002). Managing across borders: The transnational solution. Harvard Business Press.

[3] Gorbiano, M. I. (2019). One law to rule them all: Government to amend thousands of articles through omnibus bills. The Jakarta Post. 13 December 2019. Viewed 7 October 2020 . <https://www.thejakartapost.com/news/201 9/12/13/one-law-to-rule-them-allgovernment-to-amend-thousands-ofarticles-through-omnibus-bills.html.>

[4] Gürel, E., \& Tat, M. (2017). SWOT analysis: a theoretical review. Journal of International Social Research, 10(51).

[5] Gürel, E., \& Tat, M. (2017). SWOT analysis: a theoretical review. Journal of International Social Research, 10(51). 
[6] Haudi, H. W., \& Cahyono, Y. (2020). Analysis of Most Influential Factors to Attract Foreign Direct Investment. Journal of Critical Reviews, 7(13), 4128-4135.

[7] Jones, P., \& Comfort, D. (2018). The Coca Cola Brand and Sustainability. Indonesian Journal of Applied Business and Economic Research, 1(1), 34-46.

[8] Jones, P., \& Comfort, D. (2018). The Coca Cola Brand and Sustainability. Indonesian Journal of Applied Business and Economic Research, 1(1), 34-46.

[9] Kim, K. (2021). Indonesia's restrained state capitalism: Development and policy challenges. Journal of Contemporary Asia, 51(3), 419-446.

[10] Maskur, F. (2019). Dapat penghargaan indi 4.0, ini yang telah dijalankan Amatil Indonesia. Bisnis Ekonomi. 7 Mei 2019. Viewed 7 October 2020. <https://ekonomi.bisnis.com/read/20190507/ 257/919659/dapat-penghargaan-indi-4.0-iniyang-telah-dijalankan-amatil-indonesia.>

[11] Mikler, J., \& Ronit, K. (2020). Introduction: MNCs and their pathways of influence in global politics. In MNCs in Global Politics. Edward Elgar Publishing.

[12] Morgan-Thomas, A., Dessart, L., \& Veloutsou, C. (2020). Digital ecosystem and consumer engagement: A socio-technical perspective. Journal of Business Research, 121, 713-723.

[13] Rosado-Serrano, A. (2017). Franchising as strategy for internationalization of family firms: An exploratory study. Newmann Business Review, 3(1), 145-165.

[14] Saputra, R., Ridwan, M., Nasution, C. S., Ekawardani, S., \& Mafrudoh, L. (2018). The Effectiveness of Sea Toll Concept Implementation to Develop the Economic Growth in Remote Area. Advances in Transportation and Logistics Research, 1, 904-914.

[15] Susilo, D. (2018). Sacralisation Marketing Strategy (Innovative Branding for Indonesian Local Culture). BISE: Jurnal Pendidikan Bisnis dan Ekonomi, 4(1). 